\title{
Absence of fatty acid transporter CD36 protects against Western-type diet-related cardiac dysfunction following pressure overload in mice
}

Citation for published version (APA):

Steinbusch, L. K. M., Luiken, J. J. F. P., Vlasblom, R., Chabowski, A., Hoebers, N. T. H., Coumans, W. A., Vroegrijk, I. O. C. M., Voshol, P. J., Ouwens, D. M., Glatz, J. F. C., \& Diamant, M. (2011). Absence of fatty acid transporter CD36 protects against Western-type diet-related cardiac dysfunction following pressure overload in mice. American Journal of Physiology : Endocrinology and Metabolism, 301(4), E618-E627. https://doi.org/10.1152/ajpendo.00106.2011

Document status and date:

Published: 01/10/2011

DOI:

10.1152/ajpendo.00106.2011

Document Version:

Publisher's PDF, also known as Version of record

Document license:

Taverne

Please check the document version of this publication:

- A submitted manuscript is the version of the article upon submission and before peer-review. There can be important differences between the submitted version and the official published version of record.

People interested in the research are advised to contact the author for the final version of the publication, or visit the DOI to the publisher's website.

- The final author version and the galley proof are versions of the publication after peer review.

- The final published version features the final layout of the paper including the volume, issue and page numbers.

Link to publication

\footnotetext{
General rights rights.

- You may freely distribute the URL identifying the publication in the public portal. please follow below link for the End User Agreement:

www.umlib.nl/taverne-license

Take down policy

If you believe that this document breaches copyright please contact us at:

repository@maastrichtuniversity.nl

providing details and we will investigate your claim.
}

Copyright and moral rights for the publications made accessible in the public portal are retained by the authors and/or other copyright owners and it is a condition of accessing publications that users recognise and abide by the legal requirements associated with these

- Users may download and print one copy of any publication from the public portal for the purpose of private study or research.

- You may not further distribute the material or use it for any profit-making activity or commercial gain

If the publication is distributed under the terms of Article $25 \mathrm{fa}$ of the Dutch Copyright Act, indicated by the "Taverne" license above, 


\title{
Absence of fatty acid transporter CD36 protects against Western-type diet-related cardiac dysfunction following pressure overload in mice
}

\author{
Laura K. M. Steinbusch, ${ }^{1}$ Joost J. F. P. Luiken, ${ }^{1}$ Ronald Vlasblom, ${ }^{2}$ Adrian Chabowski, ${ }^{3}$ \\ Nicole T. H. Hoebers, ${ }^{1}$ Will A. Coumans, ${ }^{1}$ Irene O. C. M. Vroegrijk, ${ }^{4}$ Peter J. Voshol, ${ }^{5}$ \\ D. Margriet Ouwens, ${ }^{6}$ Jan F. C. Glatz, ${ }^{1}$ and Michaela Diamant ${ }^{7}$ \\ ${ }^{1}$ Cardiovascular Research Institute Maastricht, Department of Molecular Genetics, Maastricht University Medical Center+, \\ Maastricht; ${ }^{2}$ Laboratory for Physiology, Vrije Universiteit (VU) University Medical Center, Amsterdam, The Netherlands; \\ ${ }^{3}$ Department of Physiology, Medical University Bialystok, Bialystok, Poland; ${ }^{4}$ Endocrinology and Metabolic Diseases, Leiden \\ University Medical Center, Leiden, The Netherlands; ${ }^{5}$ Institute of Metabolic Science, University of Cambridge, Cambridge, \\ United Kingdom; ${ }^{6}$ German Diabetes Center, Düsseldorf, Germany; and ${ }^{7}$ Diabetes Center, Department of Internal Medicine, \\ VU University Medical Center, Amsterdam, The Netherlands
}

Submitted 4 March 2011; accepted in final form 25 June 2011

\begin{abstract}
Steinbusch LK, Luiken JJ, Vlasblom R, Chabowski A, Hoebers NT, Coumans WA, Vroegrijk IO, Voshol PJ, Ouwens DM, Glatz JF, Diamant M. Absence of fatty acid transporter CD36 protects against Western-type diet-related cardiac dysfunction following pressure overload in mice. Am J Physiol Endocrinol Metab 301: E618-E627, 2011. First published June 28, 2011; doi:10.1152/ajpendo.00106.2011.-Cardiac patients often are obese and have hypertension, but in most studies these conditions are investigated separately. Here, we aimed at 1) elucidating the interaction of metabolic and mechanophysical stress in the development of cardiac dysfunction in mice and 2) preventing this interaction by ablation of the fatty acid transporter CD36. Male wild-type (WT) $\mathrm{C} 57 \mathrm{Bl} / 6$ mice and $\mathrm{CD} 36^{-1-}$ mice received chow or Western-type diet (WTD) for $10 \mathrm{wk}$ and then underwent a sham surgery or transverse aortic constriction (TAC) under anesthesia. After a 6-wk continuation of the diet, cardiac function, morphology, lipid profiles, and molecular parameters were assessed. WTD administration affected body and organ weights of $\mathrm{WT}$ and $\mathrm{CD} 36^{-\prime-}$ mice, but it affected only plasma glucose and insulin concentrations in WT mice. Cardiac lipid concentrations increased in WT mice receiving WTD, decreased in $\mathrm{CD} 36^{-1-}$ on chow, and remained unchanged in $\mathrm{CD}^{-1-}$ receiving WTD. TAC induced cardiac hypertrophy in WT mice on chow but did not affect cardiac function and cardiac lipid concentrations. WTD or CD36 ablation worsened the outcome of TAC. Ablation of CD36 protected against the WTD-related aggravation of cardiac functional and structural changes induced by TAC. In conclusion, cardiac dysfunction and remodeling worsen when the heart is exposed to two stresses, metabolic and mechanophysical, at the same time. CD36 ablation prevents the metabolic stress resulting from a WTD. Thus, metabolic conditions are a critical factor for the compromised heart and provide new targets for metabolic manipulation in cardioprotection.
\end{abstract}

lipids; cardiac hypertrophy; metabolic flexibility; obesity

THE HEALTHY HEART preferably utilizes long-chain fatty acids $(60-70 \%)$ but also glucose $(30-40 \%)$, lactate, and ketone bodies $(29,37)$. Under normal conditions, there is a distinctive and finely tuned utilization balance between these fuel substrates for ATP generation such that high fatty acid supply inhibits glucose metabolism $(14,16,22)$. Under stressful conditions such as ischemia or hypertension, glucose is the pre-

Address for reprint requests and other correspondence: L. K. M. Steinbusch, Dept. of Molecular Genetics, CARIM - Maastricht University Medical Center+, P. O. Box 616 - 6200 MD Maastricht, The Netherlands (e-mail: laura.steinbusch@maastrichtuniversity.nl). ferred substrate because it requires less oxygen for its oxidation than an equimolar amount of carbons derived from fatty acids (16). Thus, the normal heart is able to switch between substrates according to the most favorable energetic yield needed for the prevailing cardiac condition (22).

Obesity, metabolic syndrome, and type 2 diabetes are associated with an increased risk of cardiovascular disease and heart failure (29). In obesity and its related conditions, plasma fatty acid and triglyceride (TG) concentrations are elevated, and plasma glucose levels gradually increase in the presence of insulin resistance (38). Collectively, these abnormalities impose metabolic stress on the heart $(21,27,40,45)$, which may ultimately lead to cardiac metabolic inflexibility, lipotoxicity (27), and subsequent development of metabolic cardiomyopathy in both rodents and humans $(19,29,33,34$, $40,44)$. Cardiac patients often are obese and have hypertension, but both conditions are studied mostly separately. In this study, we aimed at clarifying the interaction of metabolic and mechanophysical stress in the development of cardiac dysfunction.

CD36 is the predominant cardiac fatty acid transporter and is responsible for the majority of cardiac fatty acid uptake, as shown in studies with CD36 ${ }^{-1-}$ mice (18). In the normal heart, CD36 is distributed equally between the sarcolemma and intracellular membrane storage compartments. However, in rat models for obesity and insulin resistance, we and others have found that the fatty acid transporter CD36 is permanently relocated to the sarcolemma, thereby increasing the contribution of fatty acids to (cardiac) muscle energy metabolism (1, $10,32)$. This chronic increase in CD36-mediated fatty acid uptake caused 1 ) the gradual buildup of fatty acid metabolites, 2) reduced insulin-stimulated myocardial glucose uptake, measured by in vivo positron emission tomography (43) and cardiomyocyte glucose uptake $(10,32)$, and 3$)$ decreased cardiac contractile function $(32,43)$. In aging studies in mice, there was an association between CD36-mediated fatty acid uptake and age-induced diabetes and cardiomyopathy (25). However, these studies could not make any strong conclusions on the possible causal relationship between CD36 presence at the sarcolemma and the development of diabetic cardiomyopathy.

Cardiac remodeling may occur as an adaptation to the metabolic stresses mentioned above but also in response to 
mechanophysical and genetic stresses (41). Recent findings have indicated that the consequences of chronic metabolic stress and the development of metabolic inflexibility may become apparent only in the presence of additional cardiac stresses such as ischemia and hypertension $(23,26,31)$. Accordingly, it was shown that short-term lowering of plasma fatty acid levels by acipimox had no effect on cardiac function in normal controls, whereas it did affect cardiac function in patients with heart failure (42). In summary, the effect of chronic metabolic stress on mechanophysical stress is not clear yet.

In this study, we aimed at further elucidating the interaction of metabolism and function in the compromised heart. First, we hypothesized that metabolic stress and mechanophysical stress interact in the development of cardiac dysfunction in mice. Second, we hypothesized that ablation of CD36 could prevent this interaction. Mechanophysical stress was induced by pressure overload after transverse aortic constriction (TAC), and metabolic stress resulted from exposure to a Western-type diet (WTD).

A

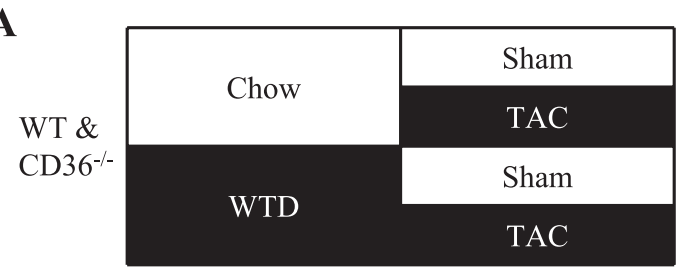

baseline

10 weeks

16 weeks

B

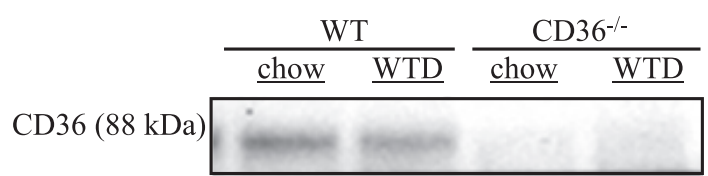

D

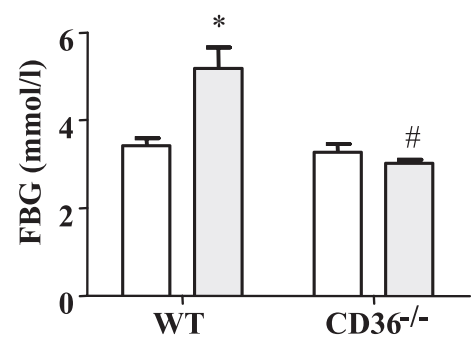

F

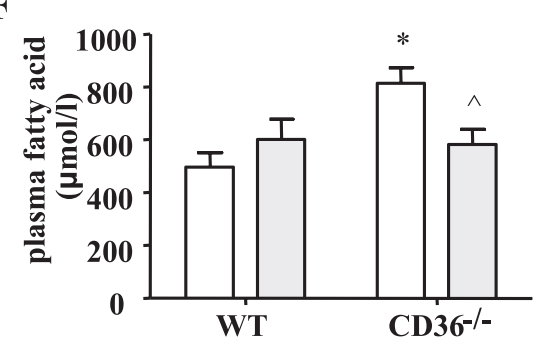

\section{EXPERIMENTAL PROCEDURES}

Twelve-week-old male wild-type (WT) and $\mathrm{CD} 36^{-1-}$ mice were fed ad libitum either standard rodent diet (chow, 1206; Harlan Teklad) or a WTD (D12079B; Open Source Research Diets). Ten weeks after initiation of the diet, mice either were sham operated (5-8 for each group) or underwent TAC (7-10 for each group) to induce pressure overload (Fig. 1A). Diet exposure was continued throughout the study. Six weeks after surgery, cardiac function was determined by echocardiography, and mice were euthanized by decapitation.

Experimental animals. $\mathrm{CD} 36^{-\prime-}$ mice were kindly provided by M. Febbraio (Cornell University, Ithaca, NY) and bred at Leiden University Medical Center (Leiden, The Netherlands). Mice were generated by targeted homologous recombination and crossed back eight times to the C57Bl/6 background (12). C57Bl/6 controls were purchased from Charles River Laboratories. All animal procedures were performed according to the Guide for the Care and Use of Laboratory Animals published by the European Commission Directive 86/609/ EEC, and in addition they were approved by the Experimental Animal Committees of Maastricht University and Leiden University Medical Center, The Netherlands.

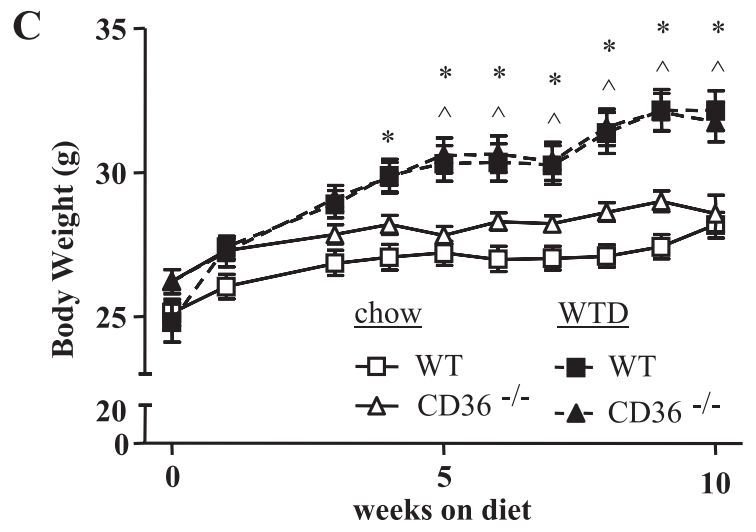

$\mathbf{E}$
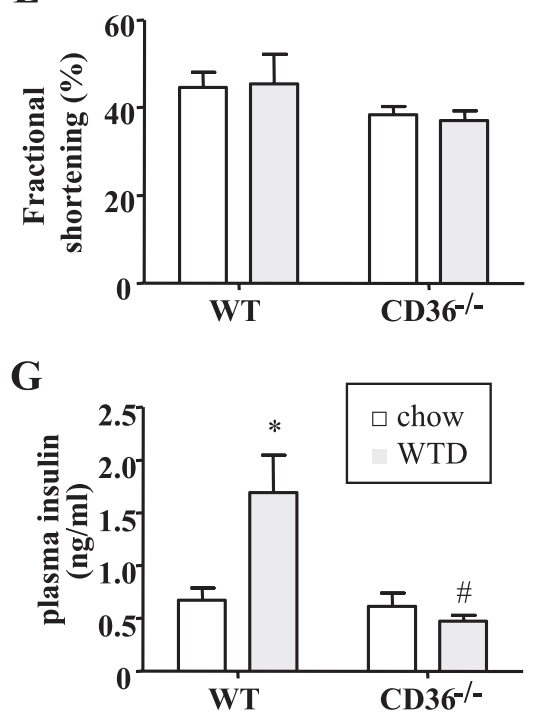

Fig. 1. Experimental setup and general parameters after $10 \mathrm{wk}$ of diet exposure. A: experimental setup. B: Western blot image of CD36 protein presence in wild-type (WT) and CD36- mice on chow or Western-type diet (WTD). $C$ : body weight during $10 \mathrm{wk}$ of diet exposure. $D$ : fasting blood glucose (FBG). $E$ : cardiac function; fractional shortening was measured by thoracic echocardiography in anesthetized mice. $F$ and $G$ : plasma fatty acid and plasma insulin concentrations after diet exposure. Data are means \pm SE from 20 mice on either diet for $A-D$ and from 6 to 8 mice/group for $E$ and $F$. Statistical analysis was done by 2-way ANOVA. *Vs. WT chow; ${ }^{\wedge}$ vs. CD36 ${ }^{-1-} /$ chow; \#vs. WT/WTD. TAC, transverse aortic constriction. 
Diet composition. Chow consisted of $330 \mathrm{kcal} / 100 \mathrm{~g}$ divided over $16 \%$ proteins, $3.5 \%$ fat (mostly palmitic and linoleic acid), and $60.89 \%$ carbohydrates (mainly starch). WTD contained $469 \mathrm{kcal} / 100$ g divided over $17 \%$ protein, $41 \%$ fat $(27.21 \%$ palmitic, $26.81 \%$ oleic, $12.41 \%$ stearic, and $10.17 \%$ myristic acid), and $43 \%$ carbohydrates (primarily sucrose).

$T A C$. TAC was performed as described previously (20). Mice were anesthetized (induction: ip ketamine-xylazine, 100 and $5 \mathrm{mg} / \mathrm{kg}$, respectively; maintenance isoflurane $1-2 \%$ ), and $0.1 \mathrm{mg} / \mathrm{kg}$ Temgesic was injected subcutaneously for pain relief. The thorax was opened at the sternum, and TAC was induced by ligation of the aortic branch around a 27 -gauge needle using a 6.0 silk suture. Sham-operated mice underwent a similar operation without the aorta being constricted.

Echocardiography. Transthoracic echocardiography was performed in anesthetized mice (3\% isoflurane induction and $0.8-1 \%$ maintenance) using an Aloka Terason 3000cv. During B-mode and M-mode, recording heart rate was kept at 500 beats/min by adjustment of isoflurane. Left ventricle (LV) fractional shortening (FS) was calculated as described previously (13). Echocardiography was performed by two persons who were blinded for experimental groups. Interindividual differences in recordings were calculated, and values were adjusted accordingly.

Organ weight and blood glucose. Body weight and blood glucose levels were determined at $12 \mathrm{wk}$ of age, after $10 \mathrm{wk}$ of diet intervention and $6 \mathrm{wk}$ after surgery. After $6 \mathrm{~h}$ of fasting, blood glucose was measured by glucose strips and a glucometer from Bayer Ascensia Contour LINK, using tail bleeds. Afterward, organs were excised, weighed, and processed for later analysis.

Histology. Deparaffinized LV sections $(4 \mu \mathrm{m})$ were stained with hematoxylin-eosin to determine cardiomyocyte cross-sectional area. Only regions that included circular-shaped cardiomyocytes with visible nuclei were analyzed. The mean cross-sectional area was determined from 60 to 100 cells for each mouse using QWin V3 software (Leica). Macrophages were visualized by a Mac3 staining (Pharmigen no. 553322) with alkaline phosphatase. The staining was scored on a five-point scale.

Heart TG, diglyceride, and ceramide concentrations. Heart lipids were determined in snap-frozen and freeze-dried tissue samples, as described previously (3). Intramyocardial lipids were extracted in methanol-chloroform, and an internal standard and water were added. One portion of the chloroform layer was used for TG and diglyceride (DG) separation, and another portion was used for ceramide determination. Afterward thin-layer chromatography was used to separate lipids, and samples were analyzed by gas-liquid chromatography.

Gene expression. Total RNA was isolated from heart tissue, as described previously (39), and converted into first-strand cDNA with the iScript cDNA synthesis kit (Bio-Rad) according to the manufacturer's instructions. Changes in gene expression were determined by quantitative PCR, as described previously (39). To standardize for the amount of cDNA, hypoxanthine phosphoribosyl transferase (HPRT) was used as a reference gene. Primer sets (Supplemental Table S1; Supplemental Material for this article is available online at the AJP-Endocrinology and Metabolism web site) were developed with Primer Express version 1.5 (Applied Biosystems, Foster City, CA) using default settings. Quantitative PCR data was analyzed according to the relative standard curve method.

Protein detection. LV homogenates were used for protein detection by SDS-polyacrylamide gel electrophoresis, followed by Western blotting, as described previously (4). Antibodies were purchased at different companies or were kind gifts (Supplemental Table S2). Western blot images were analyzed with a Molecular Imager (ChemiDoc XRS; Bio-Rad) and quantified with Quantity One (Bio-Rad).

Data presentation and statistics. Results are presented as means \pm SE. Data were analyzed by two-way ANOVA with Bonferroni post hoc test and Kaplan-Meier survival test using GraphPad Prism 5.0. Two-sided values of $P<0.05$ were considered significant.

\section{RESULTS}

Characteristics at baseline and after 10 wk of diet intervention. At $12 \mathrm{wk}$ of age, WT and $\mathrm{CD}^{-1-}$ mice had similar body weights and cardiac function (Supplemental Table S3), and CD36 ${ }^{-1-}$ mice showed no cardiac CD36 protein presence (Fig. 1B). After $10 \mathrm{wk}$ of diet intervention, mice exposed to WTD had gained significantly more body weight than those receiving chow, irrespective of the genotype (Fig. 1C). Six weeks after TAC surgery, mice receiving WTD continued to have higher body weights than mice receiving chow, regardless of the genotype (Supplemental Table S4). Remarkably, WTD-induced increases in liver mass contributed to a markedly larger extent to the increase in body weight when sham-operated $\mathrm{CD}^{-1-}$ mice were compared with WT mice (Supplemental Table S4). WTDinduced alterations in fat pad weights were similar for both genotypes (Supplemental Table S4). This relates to the notion that the genetic ablation of CD36 shifts the lipid load to tissues, such as the liver, that do not rely on CD36 for uptake of fatty acids (17).

After $10 \mathrm{wk}$ of diet intervention, WT mice receiving WTD had higher fasting blood glucose levels than WT mice receiv-

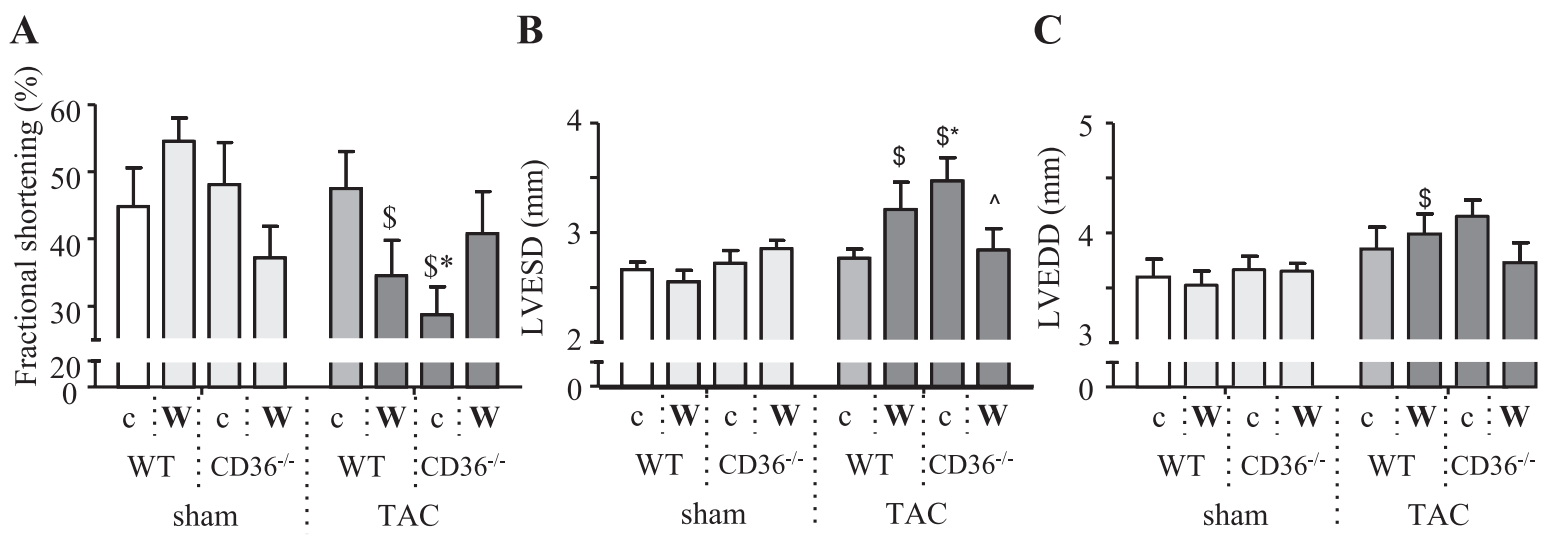

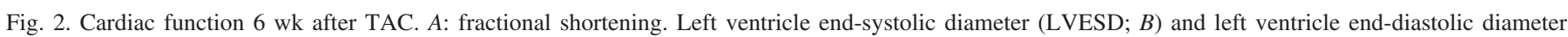

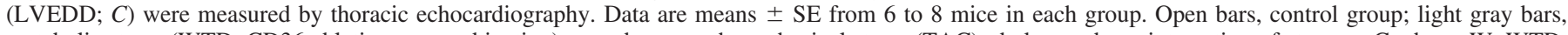

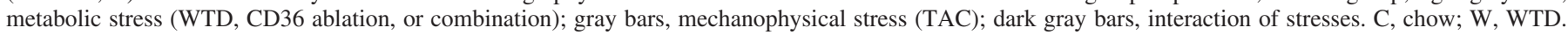
Statistical analysis was done by 2 -way ANOVA. ${ }^{*} P<0.05$ vs. WT chow; ${ }^{\wedge} P<0.05$ vs. CD36 ${ }^{-/-} / \mathrm{chow}^{*} \$ \mathrm{vs}$. sham. 
Table 1. Body weight and parameters of cardiac remodeling when mice were 28 wk old (after 16 wk of diet intervention and 6 wk of TAC)

\begin{tabular}{|c|c|c|c|c|c|c|c|c|}
\hline & \multicolumn{4}{|c|}{ Sham } & \multicolumn{4}{|c|}{ TAC } \\
\hline & \multicolumn{2}{|c|}{ WT } & \multicolumn{2}{|c|}{$\mathrm{CD} 36^{-1-}$} & \multicolumn{2}{|c|}{ WT } & \multicolumn{2}{|c|}{ CD36 $6^{-1-}$} \\
\hline & Chow & WTD & Chow & WTD & Chow & WTD & Chow & WTD \\
\hline Anterior wall thickness & $0.9 \pm 0.1$ & $1.0 \pm 0.1$ & $0.8 \pm 0.1$ & $1.0 \pm 0.1$ & $1.0 \pm 0.0$ & $1.1 \pm 0.1 \dagger$ & $1.0 \pm 0.1$ & $1.2 \pm 0.1$ \\
\hline Posterior wall thickness & $0.9 \pm 0.1$ & $1.0 \pm 0.1$ & $0.9 \pm 0.0$ & $1.0 \pm 0.0$ & $1.1 \pm 0.1$ & $1.4 \pm 0.1 * \dagger$ & $1.3 \pm 0.1 \dagger$ & $1.3 \pm 0.1 \dagger$ \\
\hline Systole & & & & & & & & \\
\hline Anterior wall thickness & $1.1 \pm 0.1$ & $1.3 \pm 0.1$ & $1.1 \pm 0.1$ & $1.2 \pm 0.0$ & $1.2 \pm 0.1$ & $1.4 \pm 0.1 \dagger$ & $1.2 \pm 0.1 \dagger$ & $1.4 \pm 0.2$ \\
\hline Posterior wall thickness & $1.3 \pm 0.1$ & $1.3 \pm 0.1$ & $1.2 \pm 0.0$ & $1.3 \pm 0.1$ & $1.5 \pm 0.1$ & $1.6 \pm 0.1 \dagger$ & $1.6 \pm 0.2$ & $1.7 \pm 0.1 \dagger$ \\
\hline Total diameter & $5.0 \pm 0.1$ & $5.3 \pm 0.1$ & $5.2 \pm 0.1$ & $5.3 \pm 0.1$ & $5.4 \pm 0.2$ & $6.3 \pm 0.3 t+$ & $6.3 \pm 0.3 \dagger$ & $6.0 \pm 0.1 \%$ \\
\hline End-systolic diameter & $2.7 \pm 0.1$ & $2.6 \pm 0.1$ & $2.7 \pm 0.1$ & $2.9 \pm 0.1$ & $2.8 \pm 0.1$ & $3.2 \pm 0.2 \dagger$ & $3.5 \pm 0.2 \dagger$ & $2.8 \pm 0.2$ \\
\hline
\end{tabular}

Values are means \pm SE. TAC, transverse aortic constriction; WT, wild type; WTD, Western-type diet. Each group consisted of $6-8$ mice. $* P<0.05$ vs. WT/chow; $\dagger P<0.05$ vs. sham; $\ddagger P<0.05$ vs. chow/sham.

ing chow (Fig. 1D), whereas fasting blood glucose concentrations did not change upon WTD administration in $\mathrm{CD} 36^{-1-}$ mice. Plasma fatty acid concentrations were elevated in both WT WTD mice and CD36 $6^{-1-}$ chow mice (Fig. $1 F$ ). WTD administration in $\mathrm{CD} 36^{-1-}$ mice resulted in a decrease in plasma fatty acid levels, suggesting that hepatic storage of fatty acid was increased. Plasma insulin levels were elevated in WT mice on a WTD compared with WT on a chow diet, whereas no alterations were seen in $\mathrm{CD} 36^{-1-}$ mice (Fig. $1 G$ ), suggesting that CD36 ablation prevents the development of WTDinduced metabolic alterations. In agreement with this, WTD administration only altered genes important in fatty acid metabolism, e.g., long-chain acetyl-CoA synthetase, in hearts of WT mice but not in $\mathrm{CD}^{-1-}$ mice (Fig. 5). Interestingly, 10 wk of WTD administration did not affect FS in any experimental group (Fig. $1 E$ ). In conclusion, WT and $\mathrm{CD}^{-1-}$ mice have similar body weights and cardiac function at $12 \mathrm{wk}$ of age. Ten weeks of metabolic stress affects body and organ weight, but not cardiac function, in both genotypes and affects only blood glucose and insulin levels in WT mice.

Parameters of cardiac function. Surgery survival was $100 \%$ for sham-operated groups for both the acute phase and
A

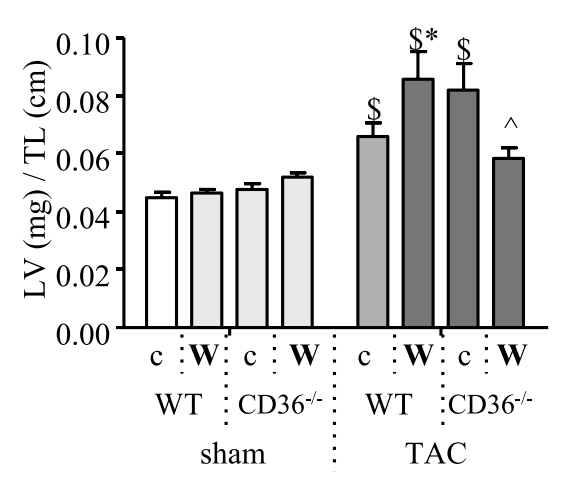

C

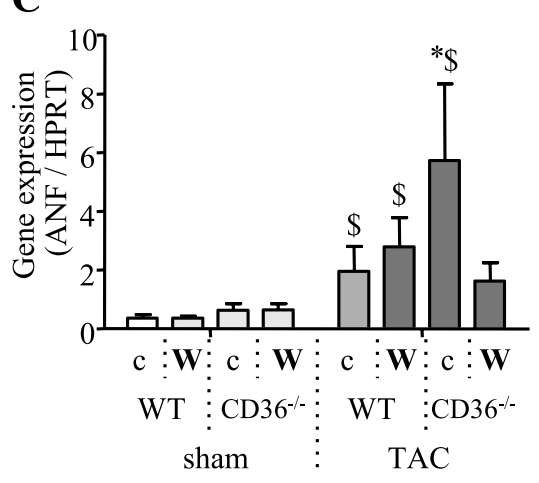

B
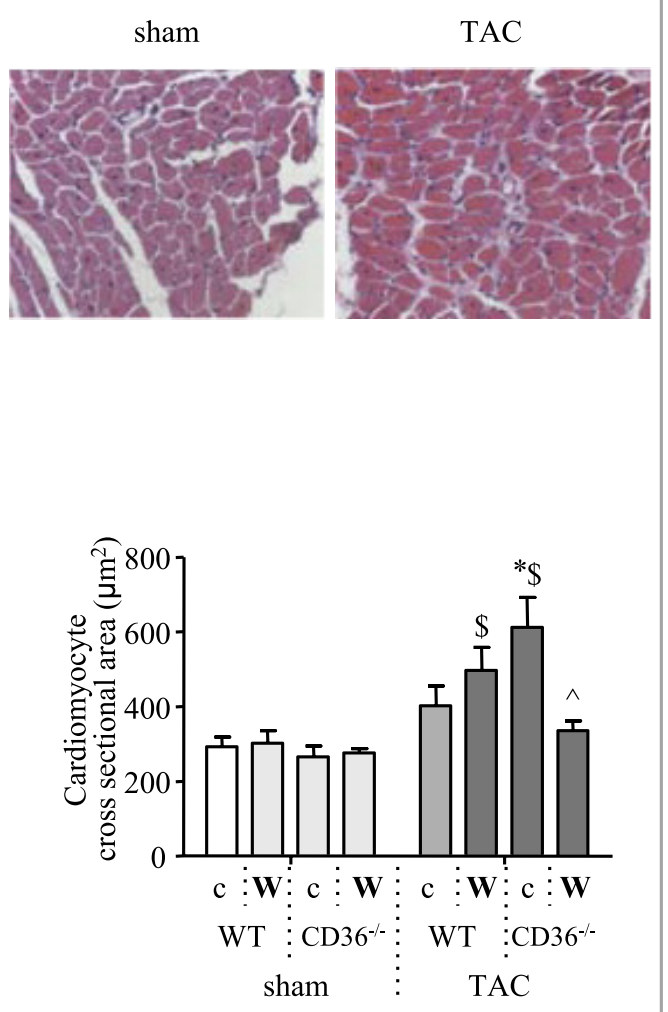

Fig. 3. Cardiac parameters 6 wk after TAC. $A$ : left ventricle (LV) weight corrected for tibia length (TL). $B$ : representative hematoxylin-eosin staining images of LV sections and analysis of cardiomyocyte cross-sectional area. $C$ : mRNA expression levels of atrial natriuretic factor (ANF), corrected for hypoxanthine phosphoribosyl transferase (HPRT) as a housekeeping gene and measured by quantitative PCR. Data are means \pm SE from 6 to 8 mice in each group. Open bars, control group; light gray bars, metabolic stress (WTD, CD36 ablation, or combination); gray bars, mechanophysical stress (TAC); dark gray bars, interaction of stresses. Statistical analysis was done by 2 -way ANOVA. $* P<0.05$ vs. WT chow; $\wedge P<0.05$ vs. CD36 ${ }^{-1-} /$ chow; $\$$ vs. sham. 
the remainder of the study. For the TAC group the survival rate was $69 \%$ for the acute phase of the TAC surgery and $73 \%$ for the remainder of the study. TAC resulted in a significant decrease in FS of $26 \%$ in WT mice receiving a WTD as well as a significant decrease in FS of $35 \%$ in $\mathrm{CD}^{2} 6^{-1-}$ mice receiving chow (Fig. 2). These changes in FS were reflected mainly in increased left ventricular end systolic diameter (LVESD; Fig. 2B); there was a strong increase in both WT WTD mice and $\mathrm{CD}^{-1-}$ chow mice. Additionally, these changes in FS resulted from increased wall thicknesses and altered LV diameters in diastole (only for WT WTD; Fig. $2 C$ and Table 1). However, cardiac function was preserved in CD36 $6^{-1-}$ on a WTD after TAC (Fig. 2), although their wall thickness was slightly increased (Table 1). No interaction of sham and WTD on cardiac function was found, regardless of the genetic background (Fig. 2), which is compatible with the lack of dietary effects in all animals prior to surgery (Supplemental Table S1 and Fig. $1 C$ ). In summary, ablation of CD36 protects against WTD-related cardiac dysfunction.
A

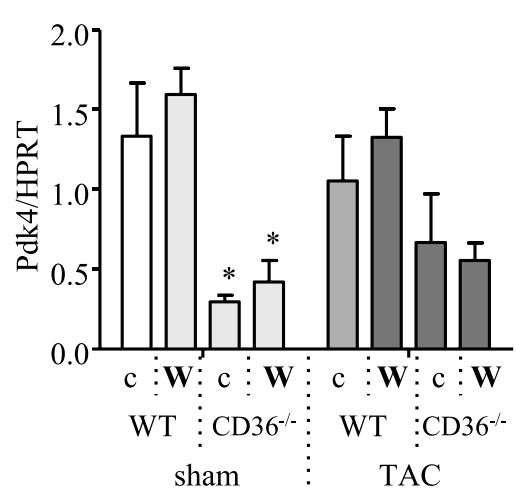

D

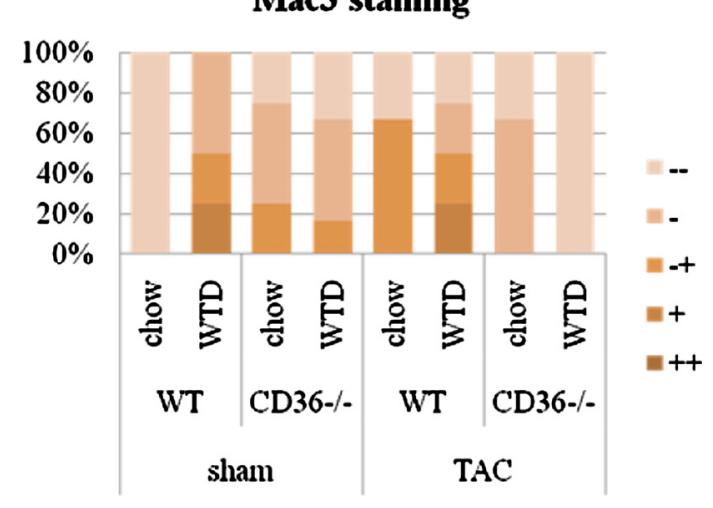

B

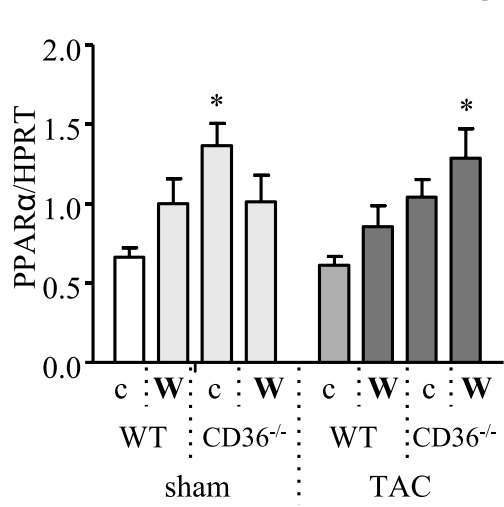

C

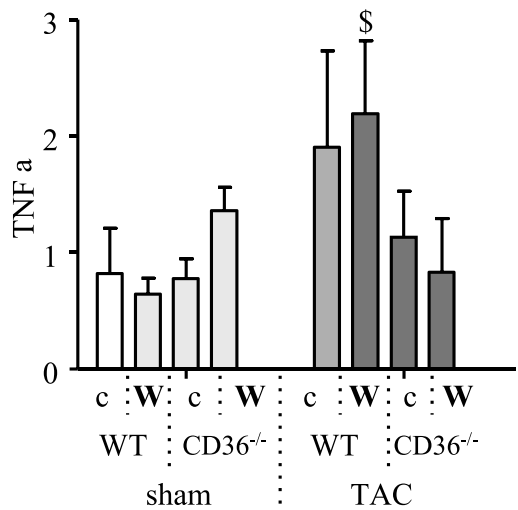

$\mathbf{E}$

Score - -

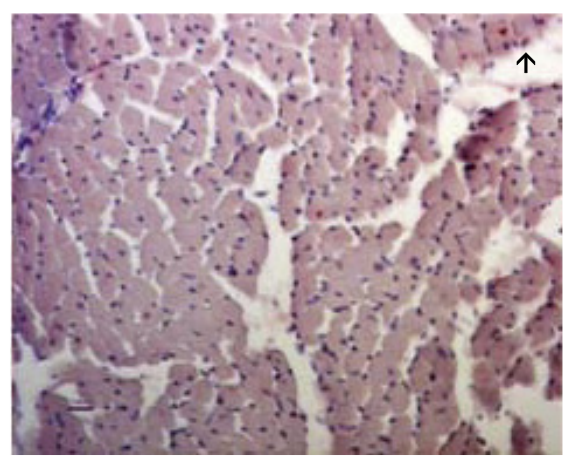

Score ++

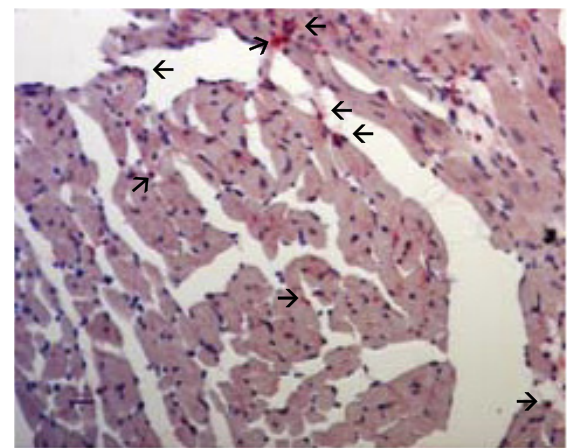

Fig. 4. Metabolic and inflammation alterations; mRNA expression of pyruvate dehydrogenase kinase-4 (Pdk4; A) and peroxisome proliferator-activated receptor- $\alpha(\operatorname{PPAR} \alpha ; B) 6 \mathrm{wk}$ after TAC. HPRT was used as a housekeeping gene. Protein presence of TNF $\alpha(C)$, quantitation of macrophage infiltration in LV sections by Mac3 staining $(D)$, and images of Mac3 staining scored $(E)$; -- (example from CD36 ${ }^{-1}$ chow TAC) and ++ (example from WT WTD sham), all 6 wk after TAC (Mac3 staining was scored on a 5-point scale; all image fields were evaluated, and the amount of cells stained by Mac3 were counted: - is the lowest amount of staining and ++ is the highest amount of staining). Data are means \pm SE from 6 to 8 mice in each group. Open bars, control group; light gray bars, metabolic stress (WTD, CD36, ablation or combination); gray bars, mechanophysical stress (TAC); dark gray bars, interaction of stresses. Statistical analysis was done by 2 -way ANOVA. ${ }^{*} P<0.05$ vs. WT chow; \$vs. sham. Arrows are directed toward Mac3-stained cells (red/pink, with a dark nucleus). 
Parameters of cardiac remodeling. Six weeks after TAC surgery, WT mice on chow showed marked signs of cardiac remodeling compared with sham-operated mice. Specifically, after TAC surgery, WT mice on chow showed increments in heart weight (1.44-fold, $P<0.05$; Supplemental Table S2), LV/tibia length (TL) (1.47-fold, $P<0.05$; Fig. $3 A$ ), and cardiomyocyte cross-sectional area (1.38-fold, $P>0.05$; Fig. $3 B$ ). Even more pronounced cardiac hypertrophy was observed after TAC surgery in the WT mice receiving WTD (vs. sham: LV/TL; 1.87 -fold, $P<0.001$ ) and $\mathrm{CD} 36^{-1-}$ mice receiving chow (vs. sham: LV/TL; 1.71-fold, $P<0.001$ ) (Fig. $3 A$ ). The combination of WTD and CD36 ablation protected the hearts from TAC-related development of more pronounced cardiac hypertrophy, as observed in WT mice on WTD and $\mathrm{CD} 36^{-1-}$ mice on a chow diet. All these changes in LV/TL were also reflected in alterations in cardiomyocyte crosssectional area (Fig. 3B). Compared with sham-operated mice, TAC increased mRNA expression of atrial natriuretic factor (ANF) in heart tissue from chow- and WTD-fed WT mice 5.4and 7.6-fold (both $P<0.05$ ), respectively, and the increase was even more marked in CD36 $6^{-1-} /$ chow mice $(9.1$-fold, $P<$ 0.01 ; Fig. $3 C$ ). Only CD $36^{-1-}$ mice receiving a WTD showed no alteration in ANF mRNA expression after TAC surgery. In sham-operated mice there was no effect of either diet or genotype on the above-mentioned parameters of cardiac hypertrophy (Fig. $3, A-C$ ). In summary, ablation of CD36 protects against cardiac remodeling.

Molecular alterations underlying cardiac dysfunction. We investigated several genes that are important in cardiac metabolism and hypertrophy. Pyruvate dehydrogenase kinase-4 (Pdk4) is important in glucose metabolism; peroxisome proliferator-activated receptor- $\alpha$ (PPAR $\alpha)$ and acyl-CoA synthetase are involved in fatty acid metabolism, whereas ANF is regulated by cardiac hypertrophy. mRNA expression of Pdk4 was decreased by $78 \%(P<0.05)$ in hearts from $\mathrm{CD} 36^{-I-}$ mice
(Fig. 4A). In addition, PPAR $\alpha$ mRNA expression changed only upon CD36 ablation; its expression increased compared with WT expression levels $(P<0.01 ;$ Fig. $4 B)$. Administration of a WTD increased cardiac mRNA expression of the PPAR $\alpha$ response gene acyl-CoA synthetase $(P<0.001 ;$ Fig. 5). In this way, the increased influx of fatty acids is directed rapidly to their metabolic destination, and the cells are protected from the detergent effects of excess fatty acid levels (15). Cardiac mRNA expression of Pdk4 and PPAR $\alpha$ was not altered by WTD or by TAC (Fig. $4, A$ and $B$ ).

Cardiac protein expression of fatty acid transporter (FATP)1, FATP6, and plasmalemmal fatty acid binding protein were not altered in $\mathrm{CD} 36^{-1-}$ mice compared with WT mice (Fig. 5). Additionally, compared with WT chow sham mice, WTD administration and/or TAC did not change the protein expression of any fatty acid transporter including CD36 (Fig. 5).

We measured carnitine palmitoyltransferase I (CPT I) mRNA expression and protein expression of oxidative phosphorylation (OxPhos) proteins to determine possible alterations in mitochondrial oxidation and metabolic inflexibility. mRNA expression of CPT I (Fig. 6), the rate-limiting enzyme in mitochondrial $\beta$-oxidation, and protein expression of mitochondrial ATP synthase and complex II in the electron transport chain (Fig. 6) were not changed upon CD36 ablation, WTD administration, or TAC surgery. The other OxPhos complexes showed the same lack of changes (data not shown).

Inflammation is known to influence the development of cardiac dysfunction. (36) Both cardiac protein levels of the proinflammatory cytokine tumor necrosis factor- $\alpha(\mathrm{TNF} \alpha)$ as presence of macrophages in LV sections were upregulated after TAC in WT mice on both diets compared with $\mathrm{CD} 36^{-1-}$ mice (Fig. 4, $C-E$ ). In sham-operated mice there was no effect of genotype or diet on TNF $\alpha$ protein expression (Fig. 4, $C-E$ ),

A
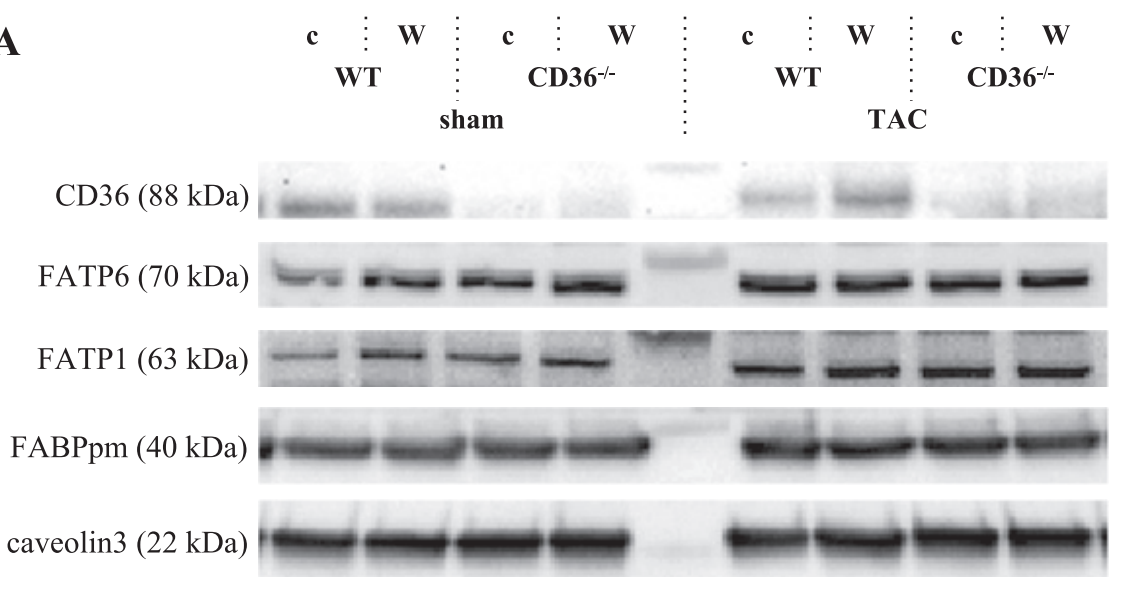

B

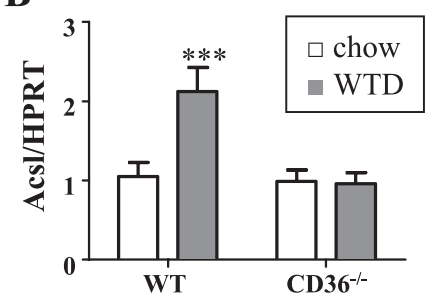

Fig. 5. Fatty acid transporters (FATP) and fatty acid handling proteins 6 wk after TAC. A: representative Western blot images of protein expression of CD36, FATP6 and -1, plasmalemmal fatty acid-binding protein (FABPpm), and caveolin-3 as loading control in LV from WT and CD36 ${ }^{-1-}$ mice on chow or WTD $6 \mathrm{wk}$ after surgery. $B$ : mRNA expression of long-chain acetylCoA synthetase (Acsl) $6 \mathrm{wk}$ after TAC surgery. HPRT was used as a housekeeping gene. Statistics was performed by 2-way ANOVA with Bonferroni posttests. $* * * P<0.001$ compared with WT chow. 
A

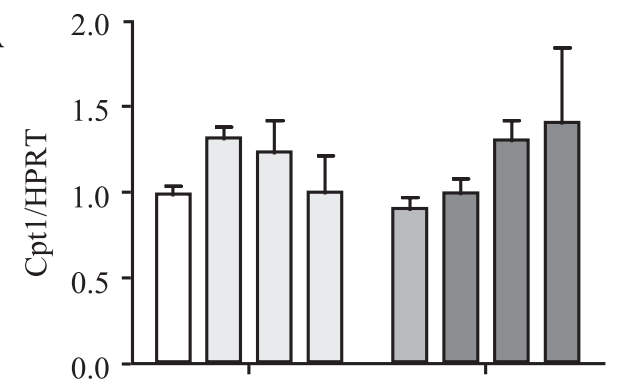

B
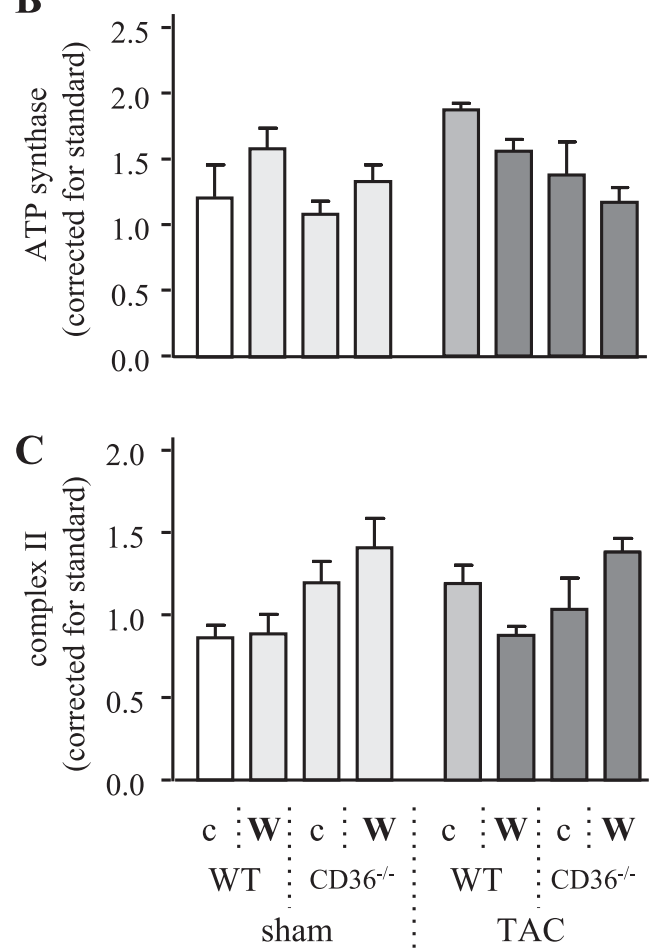

Fig. 6. Alterations in mitochondrial genes and proteins. mRNA expression levels of carnitine palmitoyltransferase I (CPT I) measured by RT-PCR $(A)$ and oxidative phosphorylation (OxPhos) protein levels ( $B$ and $C$ ), measured by Western blotting, all $6 \mathrm{wk}$ after TAC. Data are means \pm SE from 6 to 8 mice in each group. White bars, control group; light gray bars, metabolic stress (WTD, CD36 ablation, or combination); gray bars, mechanophysical stress (TAC); dark gray bars, interaction of stresses. Statistical analysis was done by 2-way ANOVA. $P<0.05$.

whereas macrophage presence in LV sections was upregulated by WTD administration in WT mice.

In conclusion, CD36 ablation protects against TAC-related increase of inflammation.

Intramyocardial lipid concentrations. In sham-operated mice, WT mice receiving a WTD showed higher cardiac TG (1.7-fold, $P<0.05$ ), DG (1.4-fold, $P<0.05$ ), and ceramide (1.8-fold, $P<0.05)$ contents than WT mice receiving chow. This confirms that WTD promotes intramyocardial lipid accumulation (Fig. 7, $A-C$ ). Sham-operated $\mathrm{CD} 36^{-1-}$ mice receiving chow showed lower intramyocardial TG $(-32 \%, P<0.05)$ and DG $(-34 \%, P<0.05)$ than sham-operated WT mice on a chow diet. WTD exposure in sham-operated $\mathrm{CD} 36^{-1-}$ mice resulted in less intramyocardial TG (1.6-fold, $P<0.05)$ and DG (1.5-fold, $P<0.05)$ accumulation and prevented ceramide accumulation compared with sham-operated WT mice receiving WTD. TAC increased intramyocardial TG, DG, and cer- amide levels (Fig. 7, $A-C$ ) (1.2- to 1.6-fold, all $P<0.05$ ). The effects of WTD and CD36 ablation on intramyocardial levels of TG, DG, and ceramide were similar in TAC compared with sham-operated mice. Lower ceramide levels could result in attenuated formation of toxic aldehydes such as 4HNE. We have measured 4HNE levels by Western blotting but did not find differences between any of the groups (Supplemental Fig. S1). In summary, ablation of CD36 protected against WTDrelated increase in cardiac lipid content.

\section{DISCUSSION}

Here we demonstrate for the first time that metabolic stress appears to be an important denominator for TAC-induced mechanophysical stress to become evident. The deleterious effect of WTD-induced metabolic stress on TAC-induced cardiac remodeling and dysfunction was prevented by ablation of the fatty acid transporter CD36. Furthermore, we revealed a tight association between intramyocellular lipid content and decreased cardiac function.

Effects of metabolic stress on cardiac morphology and function. WTD resulted in a 1.7-fold increase in cardiac lipid content in WT mice (Fig. 7), and a similar degree of lipid accumulation as found in rats exposed to a similar diet for 10 wk (32). However, WTD did not induce cardiomyopathy (Figs. 2 and 3).

WTD is known to cause a permanent relocation of CD36 to the sarcolemma and increased CD36-mediated fatty acid uptake into the heart $(1,9,32)$. In the present study, WTD administration was not accompanied by increased expression of CD36 or of other fatty acid transporters (Fig. 5). Previous studies showed that a twofold increase of FATP1 in hearts from $\mathrm{CD} 36^{-1-}$ mice did not result in enhanced fatty acid uptake in contraction-stimulated cardiomyocytes (18), suggesting that increased FATP expression cannot alter fatty acid uptake in the working heart.

A recent study showed that excessive cardiac lipid accumulation, induced by PPAR $\alpha$ overexpression, is a major causal factor for the development of cardiomyopathy (46). Ablation of CD36 proved to be protective against intramyocellular TG accumulation and cardiomyopathy. However, in our study WTD exposure did not alter PPAR $\alpha$ gene expression in WT mice or $\mathrm{CD} 36^{-1-}$ mice, which strengthens our idea that PPAR $\alpha$ overexpression is a less physiological model to induce cardiac lipid oversupply than the use of a WTD.

CD36 ablation causes a metabolic stress opposite of that elicited by WTD, an undersupply of lipids to the heart $(12,18$, 26). Accordingly, we showed that accumulation of myocardial lipids and Pdk4 expression were markedly reduced by CD36 ablation, indicating that CD36-ablated hearts rely more on glucose metabolism than do WT hearts. However, CD36 $6^{-1-}$ mice had no cardiac phenotype. In line with this, transgenic mice with cardiospecific overexpression of the glucose transporter GLUT1 exhibited reduced intramyocardial lipid content without changes in cardiac function (28).

In addition, the excessive intramyocellular lipid accumulation upon a WTD was effectively prevented by CD36 ablation.

In summary, both a WTD and CD36 ablation evoked metabolic stress on the heart, resulting in altered intramyocellular lipid concentrations compared with WT mice on a chow diet, but these changes did not result in altered cardiac function. 
A

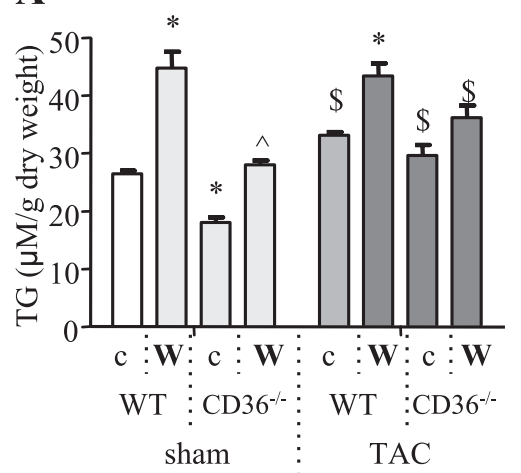

B

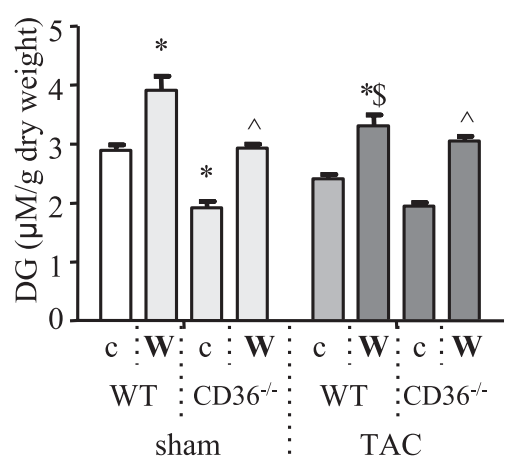

$\mathrm{C}$

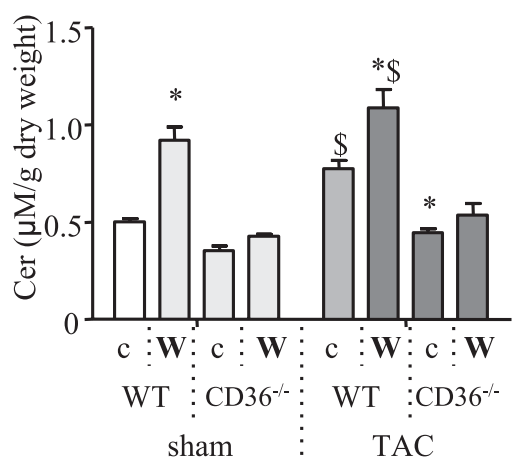

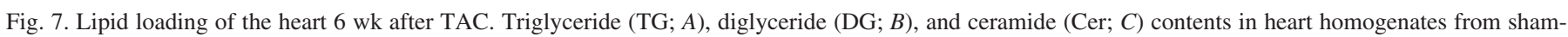

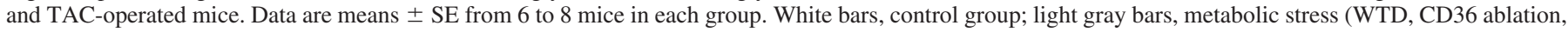

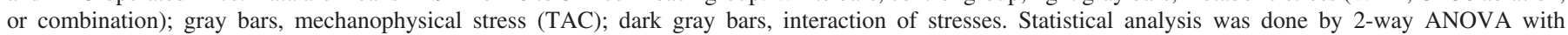

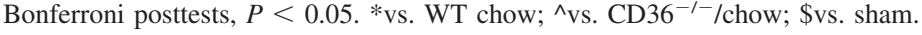

Effects of mechanophysical stress on cardiac morphology and function. TAC has been reported to increase LV pressure, to induce cardiac remodeling (20), and to provoke alterations in substrate utilization (35). In WT mice on a chow diet, we detected a $30 \%$ increase in cardiac mass due to hypertrophic growth of cardiomyocytes $6 \mathrm{wk}$ after TAC. This was accompanied by a large upregulation of ANF expression. However, this degree of hypertrophy was apparently insufficient to result in decreased function. Additionally, TAC had little or no effect on cardiac metabolic parameters, induced a slight increase in intramyocellular lipid concentrations, and did not affect gene and protein expression levels of enzymes and transporters important in substrate utilization (Figs. 4-7).

In summary, TAC induced mechanophysical stress on the heart, resulting in adaptive cardiac remodeling accompanied by only minor changes in cardiac lipid content.

Interaction between metabolic and mechanophysical stress. Patients displaying obesity and hypertension often suffer from impaired cardiac function. In our mouse model we tried to mimic this combination by starting the mice on a WTD and performing TAC afterward to induce pressure overload. We found that TAC in combination with a metabolic stress (either WTD or CD36 ablation) evoked a greater cardiac hypertrophy than TAC alone. Importantly, this greater cardiac hypertrophy was accompanied by loss of function as measured by LVESD and FS. This shows that metabolic stress, by itself not affecting cardiac fuction, aggravates the effect of mechanophysical stress on cardiac function.

In a previous study, C57B1/6 mice were exposed to a WTD or a standard diet after TAC surgery, which did not affect cardiac remodeling $(2,7)$. However, in that study the role of existing cardiac metabolic stress interacting with cardiac remodeling and dysfunction was not studied. Here, we show that existing metabolic stress interacts with later-induced cardiac mechanophysical stress.

Absence of CD36 protects against interaction of stresses. To test our hypothesis that CD36 ablation could modify the interaction between metabolic and mechanophysical stress, we evaluated whether the TAC-induced cardiac dysfunction and greater cardiac remodeling that we had observed in WT mice exposed to a WTD were altered by CD36 ablation. Interestingly, $\mathrm{CD} 36^{-/-}$mice that underwent TAC surgery during
WTD administration did not develop cardiac dysfunction, nor did they develop adverse cardiac remodeling as observed in WT mice on a chow diet. Moreover, CD36 ablation prevented the WTD-induced intramyocellular lipid accumulation in TAC-treated mice. Intramyocellular lipid alteration alone did not affect cardiac function and morphology, but it augmented hypertrophic growth of the heart and development of cardiac dysfunction in response to pressure overload. This shows that when lipid accumulation is prevented by CD36 ablation, thus eliminating metabolic stress, mechanophysical stress is no longer able to affect cardiac function.

Inflammation is known to worsen the progression toward cardiac dysfunction (6). We observed that 6 wk after TAC the proinflammatory cytokine TNF $\alpha$ and the presence of macrophages in LV sections were upregulated only in WT mice. This relates to the observations of Collot-Teixeira et al. (8) and Kennedy et al. (24), who found in mice adipocytes and macrophages that $\mathrm{CD} 36$ is needed for signaling to genes coding for an inflammatory response. This suggests that, in the heart, ablation of CD36 prevents not only fatty acid uptake but also a detrimental inflammatory reaction.

It has become increasingly evident that mitochondrial dysfunction is an important mechanism contributing to the metabolic cardiomyopathy phenotype (5). We observed that neither CPT I gene expression nor protein expression of ATP synthase and complex II of the electron transport chain was altered as a result of any of the stressors used. Although we did not measure mitochondrial oxidation, these observations suggest that cardiac mitochondrial function was not severely affected by the exposure to intramyocardial lipid levels resulting from WTD, CD36 ablation, or TAC.

Conclusions. In the presence of a mechanophysical stress, a decrease of $32 \%$ in intramyocardial lipid levels in $\mathrm{CD} 36^{-1-}$ mice and an increase of 1.7-fold in intramyocardial lipid levels in WT mice elicited by WTD are associated with impaired cardiac functioning. Combining these two observations alludes to the conclusion that, for the compromised heart, the intramyocardial lipid content should be maintained within a narrow range to maintain cardiac function. Taken together, the intramyocardial milieu, especially the lipid concentration, is a crucial factor to determine the detrimental effects of TAC on cardiac function. 
Although WTD and CD36 ablation each interact with TAC in the development of cardiac dysfunction, the combination of these interventions did not impair cardiac function. On the contrary, they counterbalanced each other, thereby revealing the metabolic origin of these cardiac diseases. These metabolic roots of cardiac dysfunction (33) imply that treatment strategies should have a metabolic character. Because prevalence of the metabolic syndrome and type 2 diabetes are rising, inhibition of CD36 can be a potential approach for treatment of metabolic cardiomyopathy.

\section{ACKNOWLEDGMENTS}

We thank L. Keersmaekers and L. Ding for their excellent technical assistance and Biomedic for lending us the Aloka Terason 3000cv.

\section{GRANTS}

This work was supported by the Dutch Diabetes Research Foundation (Grant no. 2006.00.044) and by The Netherlands Organization for Health Research and Development (NWO-ZonMw) (Grant no. 912-04-075). I. O. C. M. Vroegrijk is supported by the 7th FP of the European Union (EU)-funded "Lipidomics" (Grant no. 202272). D. M. Ouwens is supported by the EU European Cooperation in the field of Scientific and Technical Research Action BM0602 (Adipose Tissue: a Key Target for Prevention of the Metabolic Syndrome).

\section{DISCLOSURES}

The authors declare not to have any conflict of interest with respect to this article.

\section{REFERENCES}

1. Aguer C, Mercier J, Man CY, Metz L, Bordenave S, Lambert K, Jean E, Lantier L, Bounoua L, Brun JF, Raynaud de Mauverger E, Andreelli F, Foretz M, Kitzmann M. Intramyocellular lipid accumulation is associated with permanent relocation ex vivo and in vitro of fatty acid translocase (FAT)/CD36 in obese patients. Diabetologia 53: 1151$1163,2010$.

2. Akki A, Seymour AM. Western diet impairs metabolic remodelling and contractile efficiency in cardiac hypertrophy. Cardiovasc Res 81: 610617, 2009.

3. Alkhateeb H, Chabowski A, Glatz JF, Luiken JF, Bonen A. Two phases of palmitate-induced insulin resistance in skeletal muscle: impaired GLUT4 translocation is followed by a reduced GLUT4 intrinsic activity. Am J Physiol Endocrinol Metab 293: E783-E793, 2007.

4. Bonen A, Luiken JJ, Arumugam Y, Glatz JF, Tandon NN. Acute regulation of fatty acid uptake involves the cellular redistribution of fatty acid translocase. J Biol Chem 275: 14501-14508, 2000.

5. Boudina S, Abel ED. Diabetic cardiomyopathy, causes and effects. Rev Endocr Metab Disord 11: 31-39, 2010.

6. Brasier AR. The nuclear factor-kappaB-interleukin-6 signalling pathway mediating vascular inflammation. Cardiovasc Res 86: 211-218, 2010.

7. Chess DJ, Lei B, Hoit BD, Azimzadeh AM, Stanley WC. Effects of a high saturated fat diet on cardiac hypertrophy and dysfunction in response to pressure overload. J Card Fail 14: 82-88, 2008.

8. Collot-Teixeira S, Martin J, McDermott-Roe C, Poston R, McGregor JL. CD36 and macrophages in atherosclerosis. Cardiovasc Res 75: $468-$ 477, 2007.

9. Coort SL, Bonen A, van der Vusse GJ, Glatz JF, Luiken JJ. Cardiac substrate uptake and metabolism in obesity and type-2 diabetes: role of sarcolemmal substrate transporters. Mol Cell Biochem 299: 5-18, 2007.

10. Coort SL, Hasselbaink DM, Koonen DP, Willems J, Coumans WA, Chabowski A, van der Vusse GJ, Bonen A, Glatz JF, Luiken JJ. Enhanced sarcolemmal FAT/CD36 content and triacylglycerol storage in cardiac myocytes from obese zucker rats. Diabetes 53: 1655-1663, 2004.

11. Fabbri M, Di Meglio S, Gagliani MC, Consonni E, Molteni R, Bender JR, Tacchetti C, Pardi R. Dynamic partitioning into lipid rafts controls the endo-exocytic cycle of the alphaL/beta2 integrin, LFA-1, during leukocyte chemotaxis. Mol Biol Cell 16: 5793-5803, 2005.

12. Febbraio M, Abumrad NA, Hajjar DP, Sharma K, Cheng W, Pearce SF, Silverstein RL. A null mutation in murine CD36 reveals an important role in fatty acid and lipoprotein metabolism. J Biol Chem 274: 1905519062, 1999

13. Fontaine KR, Redden DT, Wang C, Westfall AO, Allison DB. Years of life lost due to obesity. JAMA 289: 187-193, 2003.

14. Glatz JF, Bonen A, Ouwens DM, Luiken JJ. Regulation of sarcolemmal transport of substrates in the healthy and diseased heart. Cardiovasc Drugs Ther 20: 471-476, 2006.

15. Glatz JF, van der Vusse GJ. Intracellular transport of lipids. Mol Cell Biochem 88: 37-44, 1989.

16. Glatz JF, Luiken JJ, Bonen A. Membrane fatty acid transporters as regulators of lipid metabolism: implications for metabolic disease. Physiol Rev 90: 367-417, 2010.

17. Goudriaan JR, Dahlmans VE, Teusink B, Ouwens DM, Febbraio M, Maassen JA, Romijn JA, Havekes LM, Voshol PJ. CD36 deficiency increases insulin sensitivity in muscle, but induces insulin resistance in the liver in mice. J Lipid Res 44: 2270-2277, 2003.

18. Habets DD, Coumans WA, Voshol PJ, den Boer MA, Febbraio M, Bonen A, Glatz JF, Luiken JJ. AMPK-mediated increase in myocardial long-chain fatty acid uptake critically depends on sarcolemmal CD36. Biochem Biophys Res Commun 355: 204-210, 2007.

19. Harmancey R, Taegtmeyer $\mathbf{H}$. The complexities of diabetic cardiomyopathy: lessons from patients and animal models. Curr Diab Rep 8: 243-248, 2008.

20. Hu P, Zhang D, Swenson L, Chakrabarti G, Abel ED, Litwin SE. Minimally invasive aortic banding in mice: effects of altered cardiomyocyte insulin signaling during pressure overload. Am J Physiol Heart Circ Physiol 285: H1261-H1269, 2003.

21. Hubert HB, Feinleib M, McNamara PM, Castelli WP. Obesity as an independent risk factor for cardiovascular disease: a 26-year follow-up of participants in the Framingham Heart Study. Circulation 67: 968-977, 1983.

22. Hue L, Taegtmeyer $\mathbf{H}$. The Randle cycle revisited: a new head for an old hat. Am J Physiol Endocrinol Metab 297: E578-E591, 2009.

23. Irie H, Krukenkamp IB, Brinkmann JF, Gaudette GR, Saltman AE, Jou W, Glatz JF, Abumrad NA, Ibrahimi A. Myocardial recovery from ischemia is impaired in CD36-null mice and restored by myocyte CD36 expression or medium-chain fatty acids. Proc Natl Acad Sci USA 100: 6819-6824, 2003.

24. Kennedy DJ, Kuchibhotla S, Westfall KM, Silverstein RL, Morton RE, Febbraio M. A CD36-dependent pathway enhances macrophage and adipose tissue inflammation and impairs insulin signalling. Cardiovasc Res 89: 604-613, 2011.

25. Koonen DP, Febbraio M, Bonnet S, Nagendran J, Young ME, Michelakis ED, Dyck JR. CD36 expression contributes to age-induced cardiomyopathy in mice. Circulation 116: 2139-2147, 2007.

26. Kuang M, Febbraio M, Wagg C, Lopaschuk GD, Dyck JR. Fatty acid translocase/CD36 deficiency does not energetically or functionally compromise hearts before or after ischemia. Circulation 109: 1550-1557, 2004.

27. Kusminski CM, Shetty S, Orci L, Unger RH, Scherer PE. Diabetes and apoptosis: lipotoxicity. Apoptosis 14: 1484-1495, 2009.

28. Liao R, Jain M, Cui L, D’Agostino J, Aiello F, Luptak I, Ngoy S, Mortensen RM, Tian R. Cardiac-specific overexpression of GLUT1 prevents the development of heart failure attributable to pressure overload in mice. Circulation 106: 2125-2131, 2002.

29. Lopaschuk GD, Ussher JR, Folmes CD, Jaswal JS, Stanley WC. Myocardial fatty acid metabolism in health and disease. Physiol Rev 90: 207-258, 2010.

30. Newton AC. Protein kinase C: structural and spatial regulation by phosphorylation, cofactors, and macromolecular interactions. Chem Rev 101: 2353-2364, 2001.

31. Opie LH, Knuuti J. The adrenergic-fatty acid load in heart failure. $J A m$ Coll Cardiol 54: 1637-1646, 2009.

32. Ouwens DM, Diamant M, Fodor M, Habets DD, Pelsers MM, EI Hasnaoui M, Dang ZC, van den Brom CE, Vlasblom R, Rietdijk A, Boer C, Coort SL, Glatz JF, Luiken JJ. Cardiac contractile dysfunction in insulin-resistant rats fed a high-fat diet is associated with elevated CD36-mediated fatty acid uptake and esterification. Diabetologia 50: 1938-1948, 2007.

33. Rijzewijk LJ, Diamant M. Diabetic Gluco-lipotoxic CardiomyopathyAmendable by Metabolic Manipulation? Eur Endocrinol 4: 54-61, 2008.

34. Rijzewijk LJ, van der Meer RW, Lamb HJ, de Jong HW, Lubberink M, Romijn JA, Bax JJ, de Roos A, Twisk JW, Heine RJ, Lammertsma AA, Smit JW, Diamant M. Altered myocardial substrate metabolism and 
decreased diastolic function in nonischemic human diabetic cardiomyopathy: studies with cardiac positron emission tomography and magnetic resonance imaging. J Am Coll Cardiol 54: 1524-1532, 2009.

35. Sambandam N, Lopaschuk GD, Brownsey RW, Allard MF. Energy metabolism in the hypertrophied heart. Heart Fail Rev 7: 161-173, 2002.

36. Satoh M, Minami Y, Takahashi Y, Nakamura M. Immune modulation: role of the inflammatory cytokine cascade in the failing human heart. Curr Heart Fail Rep 5: 69-74, 2008.

37. Schwenk RW, Luiken JJ, Bonen A, Glatz JF. Regulation of sarcolemmal glucose and fatty acid transporters in cardiac disease. Cardiovasc Res 79: 249-258, 2008.

38. Severson DL. Diabetic cardiomyopathy: recent evidence from mouse models of type 1 and type 2 diabetes. Can J Physiol Pharmacol 82: 813-823, 2004.

39. Shiri-Sverdlov R, Wouters K, van Gorp PJ, Gijbels MJ, Noel B, Buffat L, Staels B, Maeda N, van Bilsen M, Hofker MH. Early diet-induced non-alcoholic steatohepatitis in APOE2 knock-in mice and its prevention by fibrates. J Hepatol 44: 732-741, 2006.

40. Taha M, Lopaschuk GD. Alterations in energy metabolism in cardiomyopathies. Ann Med 39: 594-607, 2007.

41. Takeda N, Manabe I, Uchino Y, Eguchi K, Matsumoto S, Nishimura S, Shindo T, Sano M, Otsu K, Snider P, Conway SJ, Nagai R. Cardiac fibroblasts are essential for the adaptive response of the murine heart to pressure overload. J Clin Invest 120: 254-265, 2010.
42. Tuunanen H, Engblom E, Naum A, Nagren K, Hesse B, Airaksinen KE, Nuutila P, Iozzo P, Ukkonen H, Opie LH, Knuuti J. Free fatty acid depletion acutely decreases cardiac work and efficiency in cardiomyopathic heart failure. Circulation 114: 2130-2137, 2006.

43. van den Brom CE, Huisman MC, Vlasblom R, Boontje NM, Duijst S, Lubberink M, Molthoff CF, Lammertsma AA, van der Velden J, Boer C, Ouwens DM, Diamant M. Altered myocardial substrate metabolism is associated with myocardial dysfunction in early diabetic cardiomyopathy in rats: studies using positron emission tomography. Cardiovasc Diabetol 8: 39, 2009.

44. van der Meer RW, Rijzewijk LJ, de Jong HW, Lamb HJ, Lubberink M, Romijn JA, Bax JJ, de Roos A, Kamp O, Paulus WJ, Heine RJ, Lammertsma AA, Smit JW, Diamant M. Pioglitazone improves cardiac function and alters myocardial substrate metabolism without affecting cardiac triglyceride accumulation and high-energy phosphate metabolism in patients with well-controlled type 2 diabetes mellitus. Circulation 119: 2069-2077, 2009.

45. van Dis I, Kromhout D, Geleijnse JM, Boer JM, Verschuren WM. Body mass index and waist circumference predict both 10-year nonfatal and fatal cardiovascular disease risk: study conducted in 20,000 Dutch men and women aged 20-65 years. Eur J Cardiovasc Prev Rehabil 2009.

46. Yang J, Sambandam N, Han X, Gross RW, Courtois M, Kovacs A, Febbraio M, Finck BN, Kelly DP. CD36 deficiency rescues lipotoxic cardiomyopathy. Circ Res 100: 1208-1217, 2007.

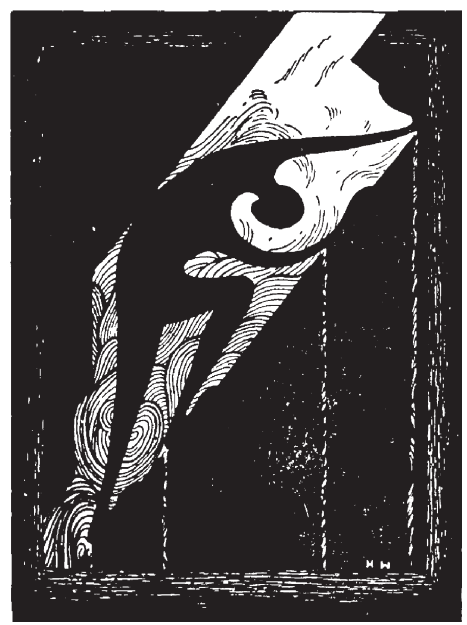

